\title{
Aesthetic and functional advantages of early orthodontic treatment in a child with
}

\section{Asperger's Syndrome: case report}

\author{
Vantagens estéticas e funcionais do tratamento ortodôntico precoce em criança com Síndrome de \\ Asperger: relato de caso clínico
}

Ventajas estéticas y funcionales del tratamiento de ortodoncia precoz en un niño con Síndrome de Asperger: reporte de caso

Layza Rossatto Oppitz ORCID: https://orcid.org/0000-0003-2672-646X Pontifícia Universidade Católica do Paraná, Brazil E-mail: layza.oppitz@yahoo.com.br Melissa Gallarza Rodríguez ORCID: https://orcid.org/0000-0003-2397-0029 Pontifícia Universidade Católica do Paraná, Brazil E-mail: meligalarza17@hotmail.com Neblyssa Ágatha Schneider ORCID: https://orcid.org/0000-0003-2631-1678 Pontifícia Universidade Católica do Paraná, Brazil

E-mail: neblyssa@gmail.com

Sara Moreira Leal Salvação ORCID: https://orcid.org/0000-0003-2361-7217 Pontifícia Universidade Católica do Paraná, Brazil

E-mail: saramoreira_ls@hotmail.com

Caroline da Paixão Custódio ORCID: https://orcid.org/0000-0002-6570-9913 Pontifícia Universidade Católica do Paraná, Brazil

E-mail: carolinepaixaocustodio@gmail.com

Andréa Paula Fregoneze

ORCID: https://orcid.org/0000-0003-4347-8445 Pontifícia Universidade Católica do Paraná, Brazil

E-mail: andrea.fregonese@pucpr.br

Patrícia Kern Di Scala Andreis

ORCID: https://orcid.org/0000-0003-4345-3803

Pontifícia Universidade Católica do Paraná, Brazil

E-mail: patriciakerndiscala@gmail.com

Ana Carolina Mastriani Arantes

ORCID: https://orcid.org/0000-0001-6787-1415

Pontifícia Universidade Católica do Paraná, Brazil E-mail: ana_mastriani@hotmail.com

Cláudia Schappo

ORCID: https://orcid.org/0000-0001-6116-1711 Pontifícia Universidade Católica do Paraná, Brazil E-mail: draclaudia.schappo@gmail.com

Odilon Guariza Filho

ORCID: https://orcid.org/0000-0001-9799-1223

Pontifícia Universidade Católica do Paraná, Brazil E-mail: odilon.filho@pucpr.br

Orlando Motohiro Tanaka

ORCID: https://orcid.org/0000-0002-1052-7872

Pontifícia Universidade Católica do Paraná, Brazil E-mail: tanaka.o@pucpr.br

Elisa Souza Camargo

ORCID: https://orcid.org/0000-0002-7382-1526

Pontifícia Universidade Católica do Paraná, Brazil E-mail: elisa.camargo@pucpr.br

\begin{abstract}
Angle Class III malocclusion results in aesthetic and functional concerns, thus it is essential that this malocclusion is treated as early as possible, so that dentocraniofacial development occurs properly. A 7-year-old male patient with
\end{abstract}


Asperger's syndrome had a Class III subdivision right malocclusion, anterior and posterior crossbite. To gain the patient's trust and collaboration, we used the behavioral management technique tell-show-do, in addition to the behavioral analysis method. Orthodontic treatment started using the Hyrax palatal expander, but the patient was not able to adapt to it. Correction of the crossbite was achieved using a removable expander with digital springs, which was better accepted by the patient and provided aesthetic and functional improvement.

Keywords: Asperger Syndrome; Malocclusion, Angle Class III; Autism disorder.

\section{Resumo}

A maloclusão de Classe III de Angle resulta em preocupações estéticas e funcionais, portanto é imprescindível que essa maloclusão seja tratada o mais precocemente possível, para que o desenvolvimento dentocraniofacial ocorra de maneira adequada. Paciente do sexo masculino, 7 anos, com síndrome de Asperger, portador de má oclusão direita subdivisão Classe III, mordida cruzada anterior e posterior. Para conquistar a confiança e a colaboração do paciente, foi utilizada a técnica de gestão comportamental tell-show-do, além do método de análise comportamental. O tratamento ortodôntico foi iniciado com o expansor palatino Hyrax, mas a paciente não conseguiu se adaptar a ele. A correção da mordida cruzada foi realizada com expansor removível com molas digitais, o que foi melhor aceito pela paciente e proporcionou melhora estética e funcional.

Palavras-chave: Síndrome de Asperger; Má oclusão Classe III de Angle; Transtorno de autismo.

\section{Resumen}

La maloclusión de Angle Class III da como resultado preocupaciones estéticas y funcionales, por lo que es esencial que esta maloclusión se trate lo antes posible, para que el desarrollo dentocraneofacial se produzca correctamente. Paciente varón de 7 años con síndrome de Asperger con maloclusión derecha subdivisión clase III, mordida cruzada anterior y posterior. Para ganarnos la confianza y la colaboración del paciente, utilizamos la técnica de manejo conductual tell-show-do, además del método de análisis conductual. El tratamiento de ortodoncia se inició con el expansor palatino Hyrax, pero la paciente no pudo adaptarse. La corrección de la mordida cruzada se logró mediante un expansor removible con resortes digitales, el cual fue mejor aceptado por el paciente y brindó mejoría estética y funcional.

Palabras clave: Síndrome de Asperger; Maloclusión de Angle Clase III; Trastorno de autismo.

\section{Introduction}

Autistic Spectrum Disorder (ASD) encompasses autism, global developmental disorder, and Asperger's syndrome (AS) (American Psychiatric Association. 2000). In most cases, the causes of ASD are unknown, however it is becoming increasingly accepted that this disorder is not simply defined as a behavioral disorder, but as a highly complex and heterogeneous biological disorder (Jaber 2011), which may result from the complex interactions between genetic, epigenetic and environmental factors (Mukherjee 2017).

AS affects $1 \%$ of the world's population (American Psychiatric Association 2013) and is the fastest growing neurodevelopmental disability worldwide (Mukherjee 2017). It is characterized by impaired social communication and the presence of stereotyped behavior (Mukherjee 2017). Delayed intellectual development is the main feature that distinguishes it from Autism (da Silva, et al. 2017). During the early developmental course, a patient diagnosed with AS is marked by a lack of any clinically significant delay in spoken language or language perception (Klin 2016).

The symptoms of this syndrome shows up before the age of three and has a steady course without remission (Jaber 2011; Barbares et al. 2006). Patients may present characteristics such as multiple nonverbal communications, impaired ability to develop social relationships and share experiences and interests, inflexible adherence to rituals (Totsika et al. 2011), as well as sensory disabilities, mental retardation or epilepsy (Barbares et al. 2006), which can make dental care difficult.

Individuals with ASD are at higher risk for Angle Class II or Class III malocclusion (Vittek et al. 1994). In the general population, Class III malocclusion shows a varied prevalence, being higher in Asian countries such as Japan and Korea (Lew et al. 1993; Woon and Thiruvenkatachari 2017). It affects between 5\% and $15 \%$ of the world population, $15.69 \%$ of the Chinese population (Burgersdijk et al. 1991) while in Europe, only 2-6\% of the population is affected (Woon \& Thiruvenkatachari 2017). The etiology of this malocclusion is multifactorial, with a strong genetic component (Battagel 1993), and may be related to maxillary skeletal retrognathism, mandibular skeletal prognathism or a combination of both (Bjerklin 
2000). This malocclusion may also have the combination of skeletal and dentoalveolar components (Bjerklin 2000) and is commonly associated with the presence of maxillary atresia, anterior and / or posterior crossbite.

Class III malocclusion (Silva Filho et al. 1990) causes severe aesthetic and functional impairment and from a therapeutic perspective, this is one of the most challenging malocclusions to be treated, with almost always an unfavorable prognosis to orthopedic and orthodontic mechanics (Silva Filho et al. 1990). Interceptive orthodontic treatment of this malocclusion should be performed as early as possible (Melsen and Melsen 1982) usually requiring maxillary arch expansion. In younger patients, this can be done with a removable expansion device or a quad-helix device after occlusal interference has been removed (Erdinc et al. 1999). Rapid maxillary expansion associated with maxillary protraction is the alternative treatment indicated when there is skeletal discrepancy, as it presents better clinical results, if possible before 8 years of age, when the circummaxillary sutures are wider (Melsen \& Melsen 1982).

We will report the case of a male patient, 7 years and 7 months old, with AS and with Angle Class III subdivision right malocclusion.

\section{Description of the Case}

The patient's parents signed the Informed Consent Form allowing the exposure of all treatment for didactic purposes.

Male patient, 7 years and 7 months, in mixed dentition phase, with SA, was referred to the Orthodontic clinic of the educational institution.

His general health was good, but due to neurological changes, he was eventually followed up with a psychologist, speech therapist, occupational therapist and neuropediatrician. He was using Methylphenidate Hydrochloride and Risperidone, he exhibited stereotypic behaviors as he often made repetitive hand movements.

According to the mother's report, the patient had taste, odors and strong noises hypersensitivity, above average intelligence for his age and did not smile often because he found his teeth ugly. She added that there was difficulty in collaborating with dental treatment, and procedures for the installation of orthodontic appliances were performed twice without success.

He had good oral health, was mesofacial and had straight profile and protruded lower lip. He presented Class III subdivision right malocclusion, maxillary atresia, anterior and posterior crossbite and anterior diastemas in both dental arches (Figures 1, 2 and 3). Radiographically, the permanent teeth were in intraosseous development, with normality in all tissues (Fig. 3). Cephalometric analysis indicated Class I skeletal pattern and marked buccal inclination of the lower incisors [Table 1]. He had predominantly mouth breathing, but phonation and swallowing were normal. 
Figure 1. Extra extraoral photographs (7 years and 7 months old) of the patient, with Angle Class III subdivision right malocclusion and anterior and posterior crossbite.
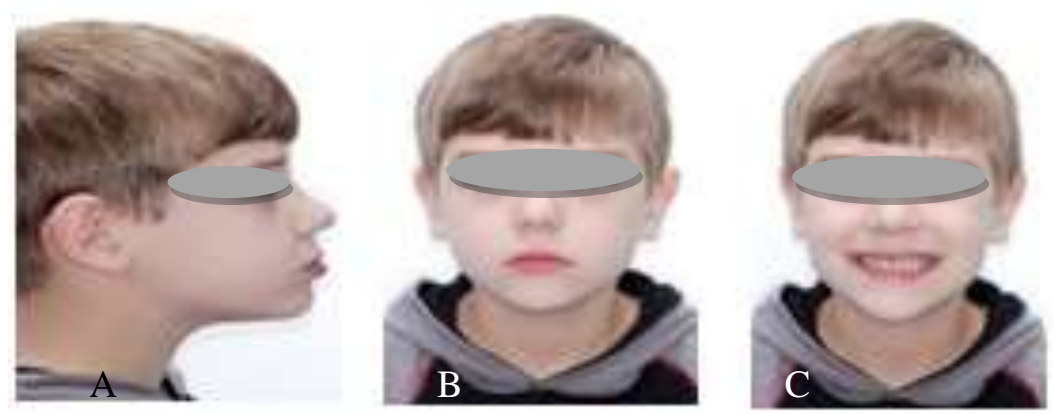

Source: Authors.

Figure 2. Intraoral photographs (7 years and 7 months old) of the patient, with Angle Class III subdivision right malocclusion and anterior and posterior crossbite.
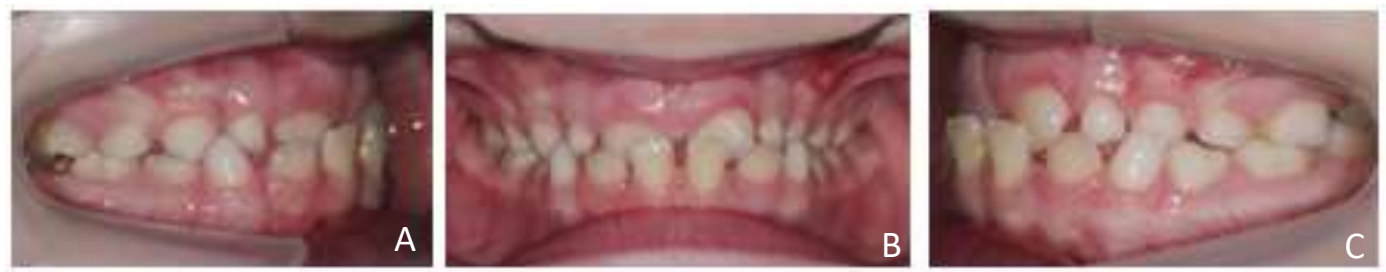

Source: Authors.

Figure 3. Occlusal photographs (A and B) (7 years and 7 months old) of the patient, with Angle Class III subdivision right malocclusion and anterior and posterior crossbite and Initial panoramic radiograph $(\mathrm{C})$ showing normal dentition development.
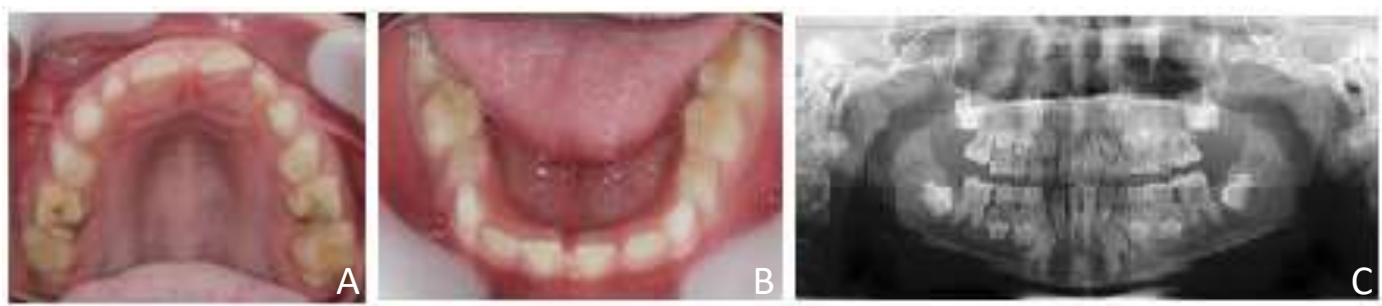

Source: Authors. 
Table 1. Initial and final cephalometric measurements.

\begin{tabular}{|c|c|c|c|}
\hline & & INITIAL & FINAL \\
\hline Cephalometric Measures & Normal & 7,7 years & 9,9 years \\
\hline \multicolumn{4}{|l|}{ Skeletal } \\
\hline$\overline{\left.\text { SNA ( }{ }^{\circ}\right)}$ & 82 & 86 & 83 \\
\hline $\operatorname{SNB}\left({ }^{\circ}\right)$ & 80 & 85 & 81 \\
\hline ANB (०) & 2 & 1 & 2 \\
\hline Convexity (०) & 0 & 1 & 1 \\
\hline $\mathrm{Y}$ axis $\left({ }^{\circ}\right)$ & 59,9 & 55 & 56 \\
\hline Facial axis $\left({ }^{\circ}\right)$ & 87,8 & 91 & 89 \\
\hline SN-GoGn (०) & 32 & 28 & 30 \\
\hline FMA (०) & 25 & 19 & 25 \\
\hline
\end{tabular}

Dentoalveolar

\begin{tabular}{l|c|c|c}
\hline IMPA (०) & 90 & 105 & 90 \\
1.NA (०) & 22 & 24 & 30 \\
1-NA (mm) & 4 & 3 & 5 \\
1.NB (०) & 25 & 37 & 21 \\
1-NB (mm) & 4 & 6 & 5 \\
Interincisal Angle (०) & 131 & 120 & 126 \\
\hline
\end{tabular}

\section{Soft Tissues}

Upper lip - S-line (mm)

Lower lip - S-line (mm)

Z -Angle (०)

\begin{tabular}{c|c|c}
\hline 0 & 0 & -1 \\
0 & 3 & 2 \\
75 & 76 & 78 \\
\hline
\end{tabular}

Source: Authors.

Before starting the orthodontic treatment, an initial approach was taken to obtain the patient's confidence through the behavioral analysis method (ABA) method and the tell-show-do management technique (Hernandez \& Ikkanda 2011). Although Hernandez cites the possible ineffectiveness of procedures such as tell-show-do in patients with AS, a good result was obtained for this child. Based on this method, parents obtained more collaboration in daily activities when they explained to the their child in detail about the daily routine, including the appointments, the people involved in them, and the possible noises, odors, and textures he would come into contact with.

Thus, knowing the environmental factors that influenced the patient's subject's behavior in the clinic, prior to the appointment, the mother would describe all the procedures to be performed and the orthodontist reinforced the explanation at the time of care. Another fact that helped with the treatment was the prizes promised to him at the end of the week, based on the level of collaboration and engagement. Parents marked in a chart the score for each activity performed, which added up to a star at the end of the day. If there was collaboration in visiting the orthodontist, he would get an extra star. Furthermore, there was a routine in appointments, which were always held in the same clinic and dental chair and by the same dentist, which would give the patient a feeling of greater safety. The use of electronic gaming equipment during the appointment also calmed him down.

The first treatment option was rapid maxillary expansion and protraction. The treatment was started with the Hyrax palatal expander, with maxillary protraction hooks and digital springs for projection of the upper incisors (Figure 4A), but the patient did not adapt to this device, reporting discomfort and difficulty to speak and parents had difficulty performing screw activations. Therefore, after 3 months it was decided to remove this device and make a removable appliance with expander 
screw, digital springs and posterior bite plane, which was better accepted by the patient and used for 8 months (Figure 4B). The expander screw was activated $1 / 4$ turn and the digital springs approximately $1.0 \mathrm{~mm}$ every 30 days.

Figure 4. Occlusal photographs of the Hyrax palatal expander with digital springs and hooks for maxillary protraction (A) and removable expander with digital springs and posterior bite plane (B)

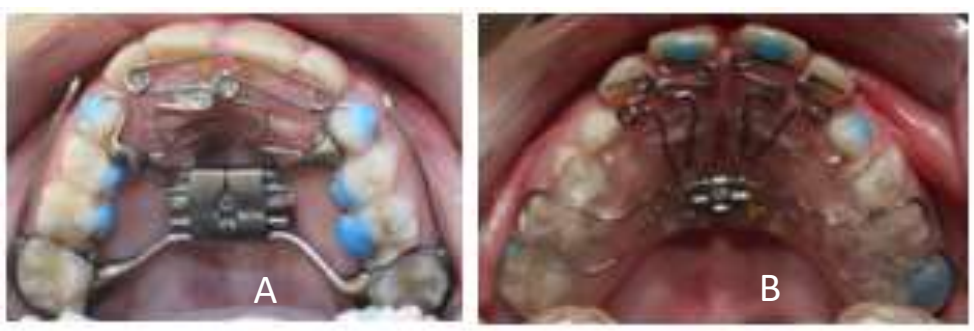

Source: Authors.

At the end of the treatment, a slight expansion of the upper arch and an anterior crossbite correction with significant aesthetic and functional improvement were obtained (Figure 5 and 6). Panoramic radiography shows soft and hard tissue images consistent with normality patterns (Figure 7). Superimposition of the initial and final cephalometric tracings (Figure 10) shows the incisor crossbite correction, lower third harmony of the face due to improved lower lip position and harmonic growth of the face.

Figure 5. Extraoral photographs ( 9 years and 9 months old), showing the correction of the anterior crossbite and consequent improvement in the position of the lower lip.
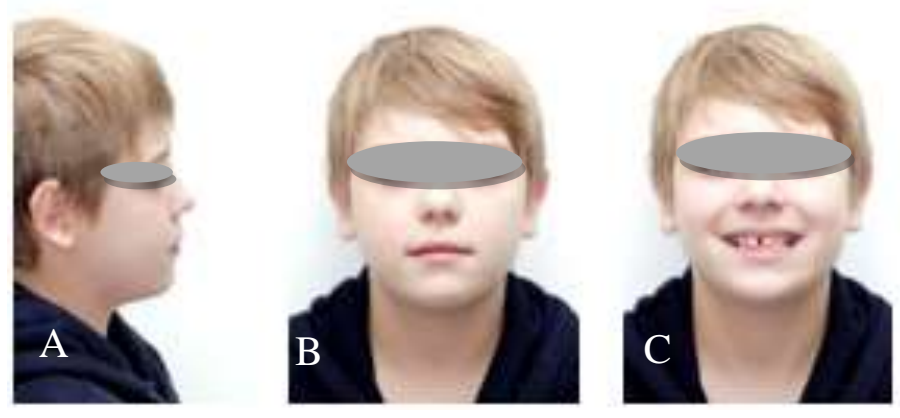

Source: Authors.

Figure 6. Intraoral photographs (9 years and 9 months old), showing the correction of the anterior crossbite and consequent improvement in the position of the lower lip.
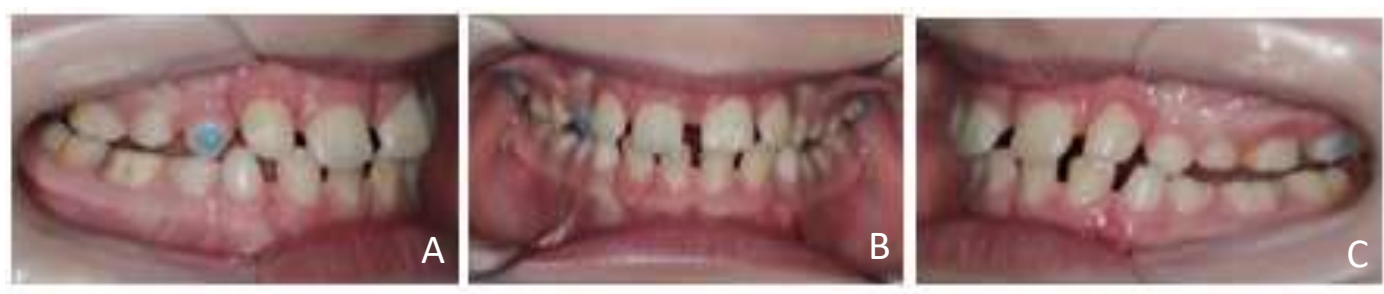

Source: Authors. 
Figure 7. Occlusal photographs (A and B) (9 years and 9 months old), showing the correction of the anterior crossbite and consequent improvement in the position of the lower lip and final panoramic radiograph (C) showing normality of the tissues
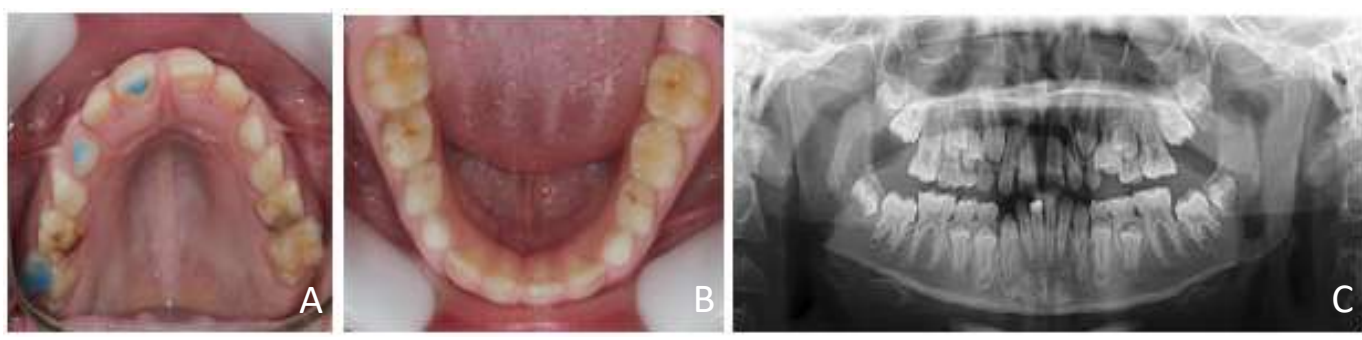

Source: Authors.

After completion of the treatment, periodic clinical evaluations were performed on the patient for one year and the stability of the results, as well as an improvement of the vertical relationship between the dental arches were observed (Figure 8,9 and 10).

Figure 8. Extraoral photographs after treatment (10 years and 9 months).
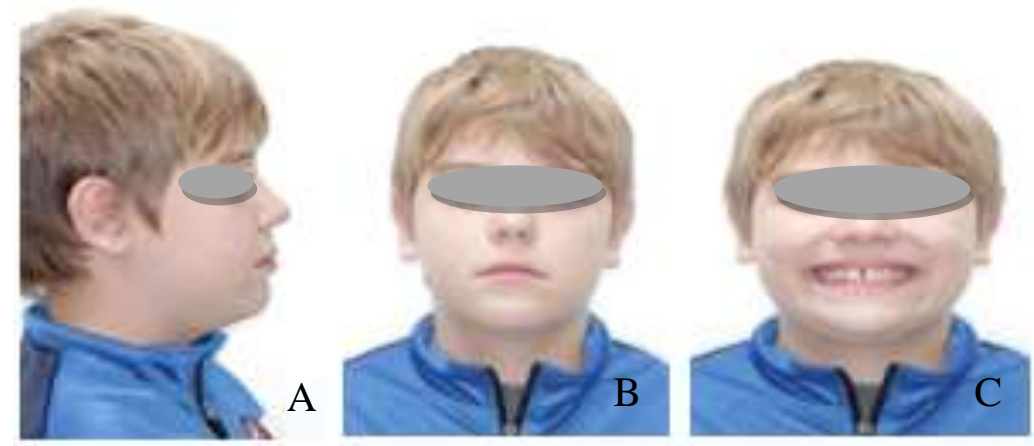

Source: Authors.

Figure 9. Intraoral photographs after treatment (10 years and 9 months).
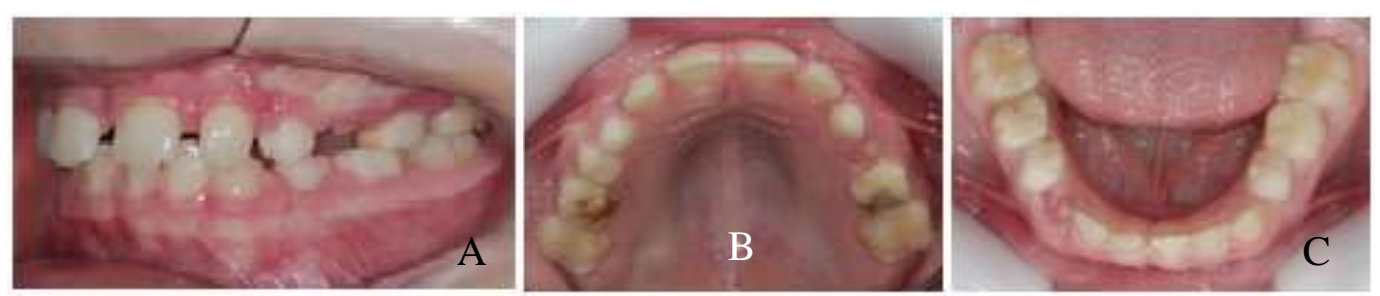

Source: Authors.

Figure 10. Occlusal photographs and superimposition initial ( 7 years and 7 months) and final (9 years and 9 months)
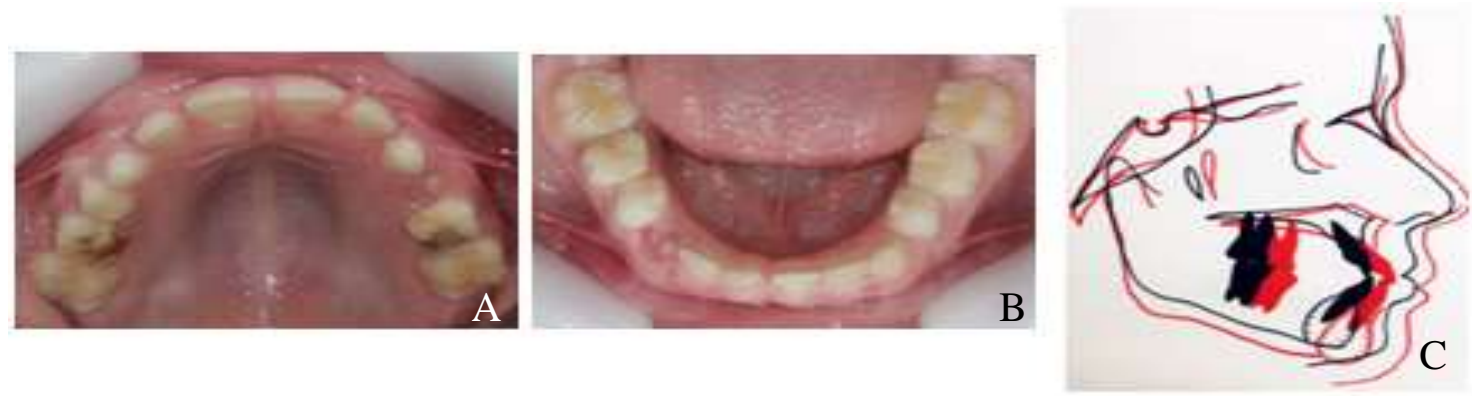

Source: Authors. 


\section{Discussion}

The patient reported here had Angle's Class III malocclusion, corroborating the literature, which states that individuals with ASD are at higher risk for this malocclusion (Vittek et al. 1994). Interceptive orthodontic treatment of Class III malocclusion should ideally be performed by rapid maxillary expansion associated with protraction, as it will improve not only dental deviations but also skeletal discrepancy (Oltramari-Navarro et al. 2013). This mechanics is especially indicated when there is maxillary retrognathism, whether or not accompanied by mandibular prognathism (Kama et al. 2006). The treated patient had orthognathic maxilla and mandible. However, in addition to the Class III dental relationship on the right side, cephalometric measurements showed a tendency to skeletal Class III, so it was initially planned to perform maxillary expansion and protraction. However, it was not possible to perform this orthodontic mechanics, since he was very uncomfortable with the palatal expander removed with few activations and before the installation of the face mask that would promote the anchorage for reverse traction of the jaw.

After removal of the Hyrax palatal expander, the installation and activations of the removable expander were better accepted by the patient. The force of activation of the digital springs caused inclination movement of the upper incisors, correcting the anterior crossbite. With normal overjet restored, the lower incisors that were with buccal inclination, inclined to lingual, acquiring better position. Although it was not possible to perform rapid palatal expansion, periodic activation of the removable appliance screw allowed the correction of the posterior crossbite. According to Haas (HAAS 1970; HAAS 1953; HAAS 1961 and HAAS 1965), in the presence of skeletal posterior crossbite, the most effective treatment is the maxillary midpalatal suture disjunction, but in the treatment reported here, it was not possible due to the behavioral limitations of the patient.

It is suggested that such limitations are related to the patient's inability to develop joint attention, which, according to Totsika (Totsika et al. 2011), generates a lack of curiosity for the environment and lack of ability to share information using spoken language, gestures and eye contact, which are common in patients with TEA. In addition, they present impaired sensory perception, thus, malfunction in stimulus interpretation can result in aberrant responses to visual, auditory, tactile, olfactory and taste signals (Stein et al. 2011). This patient was sensitive to these signs and at the beginning of the treatment reacted with screams when something bothered him, even with the extra medication given before the appointments (Methylphenidate Hydrochloride and Risperidone) and with the previous explanation about the procedures by the orthodontist before the beginning of the appointment.

Although several professionals previously denied orthodontic care to the patient because of his behavioral condition, it was possible to obtain his collaboration through the tell-show-do management technique and short, clear commands such as "hands down" and "look at me" (Klein and Nowak 1988), by the voice modulation technique (American Psychiatric Association. 2013). It was observed that the fact that the dental care was always performed at the same clinic and by the same professional who explained in detail how the appointment would be promoted a routine, which is of paramount importance to obtain collaboration in patients with AS (Menezes and de Souza 2015).

Possibly the use of the ABA method in dental appointments, as used by the family during the patient's daily life, helped to improve the patient's behavior during dental appointments. This method recommends careful assessment of how environmental events interact to influence the behavior of the patient affected by this syndrome and the information resulting from this assessment leads to the design, implementation and further evaluation of environmental interventions designed to change behaviors (Vismara and Rogers 2010).

Likewise, the presence of the mother near the dental chair in all appointments was important to gain the patient's confidence in the procedures performed. According to Klein and Nowak (1988) and Robson and Milius (1976) the presence of parents is recommended during dental treatment of the patient with ASD. Probably, the collaboration was also obtained due to 
the mild level - 1 of the ASD presented by the patient, diagnosis provided by the neuropediatrician. The dental professional during the exam should keep in mind that individuals with AS have wide variation in skills, intelligence and performance (Erdinc et al. 1999). Due to the multifaceted symptomatology of ASD, professionals need to achieve a specific therapeutic approach according to each child's individual characteristics (Delli et al. 2013).

Younger children with ASD may respond better to certain management techniques, such as positive reinforcement (Delli et al. 2013). This technique was applied in the case reported here, through compliments made by the orthodontist and the awards the patient received from his parents, like candies, ice cream or toys. Ingvarsson, Kahng, and Hausman (2008), reported that this technique may not guarantee the future occurrence of the desired behavior in people with ASD, but in the present case there was an improvement in the behavior during the treatment.

Overall, the treatment outcome was positive, with significant aesthetic and functional improvement and stability. In addition to correcting the anterior crossbite, which certainly brought benefits for occlusion, the patient and family members were pleased with the result. Follow-up of patient's development of dentition and occlusion will continue to be performed to confirm the need of corrective orthodontic treatment.

The orthodontic treatment of patients with special needs is challenging; however, the patient's inherent limitations to the syndrome have been overcome, enabling the correction of malocclusion and establishing strong bonds of trust between the patient, family and professionals involved.

\section{Conclusion}

The interceptive treatment of Angle Class III malocclusion in a patient with Asperger's syndrome presents some difficulties, but it can be performed as long as the child is assisted by a multidisciplinary team including a psychologist, an orthodontist, a speech therapist, an occupational therapist and a neuropediatrician and as long as the dental surgeon is aware of the limitations and how to handle them during the appointments. In the reported case, occlusion deviations were corrected and behavior control and patient confidence gain will facilitate future treatments.

\section{References}

American Psychiatric Association. (2000). Diagnostic and Statistical Manual of Mental Disorders, 4th ed. PDD-NOS. American Psychiatric Association.

American Psychiatric Association. (2013). Autistic spectrum disorders. In: Diagnostic and statistical manual of mental disorders, (5th ed.), Arlington: American Psychiatric Association, 50-9.

Barbaresi W. J., Katusic S. K., \& Voigt R. G. (2006) Autism: a review of the state of the science for pediatric primary health care clinicians. Archives of Pediatrics \& Adolescents Medicine, 160:1167-75.

Battagel J. M. (1993). The aetiological factors in class III malocclusion. European Journal of Orthodontics, 15:347-370.

Bjerklin K. (2000). Follow-up control of patients with unilateral posterior cross-bite treated with expansion plates or the quad-helix appliance. Journal of Orofacial Orthopedics, 61:112-24.

Burgersdijk R., Truin G. J., Frankenmolen F., Kalsbeek H., van't Hof M., \& Mulder J. (1991). Malocclusion and orthodontic treatment need of 15-74-year-old Dutch adults. Community Dentistry and Oral Epidemiology, 19(2):64-67.

da Silva, M. B., Gomes, C. A., \& Lopes-Herrera, S. A. (2017) Desenvolvimento fonológico em crianças com transtorno do espectro Autista- Síndrome de Asperger. Linguística Rio, (3a ed.)

Delli K., Reichart P. A., Bornstein M. M., \& Livas C. (2013). Management of children with autism spectrum disorder in the dental setting: concerns, behavioural approaches and recommendations. Medicina Oral Patologia Oral Cirurgia Bucal, 18: e862-868.

Erdinc A., Ugur T., \& Erbay E. (1999) A comparison of different treatment techniques for posterior crossbite in the mixed dentition. American Journal of Orthodontics and Dentofacial Orthopedics, 116:287-300.

HAAS A. J. (1953). Gross reaction to the widening of the maxillary dental arch of the pig by splitting the hard palate.1953. 36 f. Master Thesis, Chicago.

HAAS A. J. (1961). Rapid expansion of the maxillary dental arch and nasal cavity by opening the midpalatal suture. The Angle Orthodontis, .31(2)73-90. 
HAAS A. J. (1965). The treatment of maxillary deficiency by opening the midpalatal suture. The Angle Orthodontist, 35:(3)200-217.

HAAS A. J. (1970). Palatal expansion: just the beginning of dentofacial orthopedics. American Journal of Orthodontics and Dentofacial Orthopedics, 57:(3)219-255.

Hernandez P., \& Ikkanda Z. (2011). Applied behavior analysis: behavior management of children with autism spectrum disorders in dental environments. Journal of the American Dental Association, 142:281-287.

Ingvarsson E. T., Kahng S., \& Hausman N. L. (2008). Some effects of noncontingent positive reinforcement on multiply controlled problem behavior and compliance in a demand context. Journal of Applied Behavior Analysis, 41(3):435-40.

Jaber M. A. (2011) Dental caries experience, oral health status and treatment needs of dental patients with autism. Journal of Applied Oral Science, 19:212-7.

Kama J. D., Ozer T., \& Baran S. (2006). Orthodontic and orthopaedic changes associated with treatment in subjects with Class III malocclusions. European Journal of Orthodontics, 28:496-502.

Klein U., \& Nowak A. J. (1988). Pediatric Dentistryt Journal, Autistic disorder: a review for the pediatric dentist.20(5):312-7.

Klin A. (2016) Autism and Asperger syndrome: an overview. Brazillian Journal of Psychiatry, 28 Suppl 1:S3-11.

Lew K. K., Foong W. C., \& Loh E. (1993) Malocclusion prevalence in an ethnic Chinese population. Australian Dental Journal, $38(6): 442-449$.

Melsen B., \& Melsen F. (1982) The postnatal development of the palato- maxillary region studied on human autopsy material. American Journal of Orthodontics and Dentofacial Orthopedics, 82(3):329-342.

Menezes, L. C., \& de Souza, K. A (2015). Para além dos déficits: interação e atenção conjunta em crianças com autismo. Psicologia em Estudo, 20(3)353-364.

Menezes, L. C., \& de Souza, K. A. (2015) Para além dos déficits: interação e atenção conjunta em crianças com autismo. Psicologia em Estudo, 20:(3)353364.

Mukherjee S. B. (2017) Autism Spectrum Disorders - Diagnosis and Management. The Indian Journal of Pediatric, 84:307-314.

Oltramari-Navarro P. V., de Almeida R. R., Conti A. C., Navarro R. de L., de Almeida M. R., \& Fernandes L. S. (2013). Early treatment protocol for skeletal Class III malocclusion. Brazillian Dental Journal, 24:167-173.

Robinson, M. D., \& Milius, A. C (1976). Childhood autism in: Dentistry for the handicapped child. St. Louis: The C.V. Mosby Company; 102-120. (Nowak $A J, e d$.

Silva Filho O. G., Freitas S. F., \& Cavassan A. O. (1990). Prevalence of normal occlusion and malocclusion in Bauru (São Paulo) students. Revista de Odontologia da Universidade de São Paulo, 4:189-196.

Stein L. I., Polido J. C., Mailloux Z., Coleman G. G., \& Cermak S. A (2011). Oral care and sensory sensitivities in children with autism spectrum disorders. Special Care Dentistry, 31:102-10.

Totsika V, Hastings R. P., Emerson E., Lancaster G. A., \& Berridge D. M. (2011). A population-based investigation of behavioural and emotional problems and maternal mental health: associations with autism spectrum disorder and intellectual disability. Journal of Child Psychology and Psychiatry, 52:91-9.

Vieira B. B., Sanguino A. C., Moreira M. R., Morizono E. N., \& Matsumoto M. A. (2013). Surgical-orthodontic treatment of Class III malocclusion with agenesis of lateral incisor and unerupted canine. Dental Press Journal of Orthodontics, 18(3):94-100.

Vismara L. A., Rogers S. J. (2010). Behavioral treatments in autism spectrum disorder: what do we know? Annual Review of Clinical Psychology, 6:447-468.

Vittek J., Winik S., Winik A., Sioris C., Tarangelo A. M., \& Chou M. (1994) Analysis of orthodontic anomalies in mentally retarded developmentally disabled (MRDD) persons. Special Care Dentistry, 14(5):198-202.

Woon S. C., \& Thiruvenkatachari B. (2017). Early orthodontic treatment for Class III malocclusion: A systematic review and meta-analysis. American Journal of Orthodontics and Dentofacial Orthopedics, 151:28-52. 